\title{
Pemanfaatan Energi Surya pada Kapal Penangkap Ikan 10 GT sebagai Sarana Perlistrikan Alternatif di PPI Cituis Kabupaten Tangerang
}

\author{
Bambang Sudjasta $^{1 *}$, Donny Montreano ${ }^{2}$, Sugeng Prayitno $^{3}$ \\ ${ }^{1}$ Program Studi Teknik Perkapalan, Fakultas Teknik, UPN “Veteran” Jakarta, 16515 \\ ${ }^{2}$ Program Studi Teknik Industri, Fakultas Teknik, UPN “Veteran” Jakarta, 16515 \\ ${ }^{3}$ Program Studi Teknik Mesin, Fakultas Teknik, UPN "Veteran” Jakarta, 16515
}

*Korespondensi penulis: bambangsudjasta@upnvj.ac.id

\begin{abstract}
Abstrak. Potensi sumber daya perikanan laut Indonesia besarnya \pm 6.6 juta ton/tahun, tetapi baru sebagian yang dapat ditangkap oleh nelayan Indonesia yaitu \pm 4.7 juta ton/tahun, sebagian lagi dicuri oleh nelayan-nelayan negara tetangga (ilegal fishing). Hal ini disebabkan terbatasnya jumlah dan besar ukuran kapal ikan yang beroperasi. Salah satu wilayah yang mempunyai potensi perikanan tangkap adalah Kecamatan Pakuhaji Kabupaten Tangerang Provinsi Banten. Kecamatan Pakuhaji mempunyai wilayah pesisir yang berhadapan langsung dengan Laut Jawa. Wilayah ini memiliki garis pantai \pm 6 (enam) kilometer. Wilayah ini terdapat Pangkalan Pendaratan Ikan (PPI) Cituis, tepatnya berada di Desa Surya Bahari. Dalam rangka meningkatkan kemampuan para nelayan di Kecamatan Pakuhaji Kabupaten Tangerang, maka perlu pada kapal penangkap ikan dipasang sistem perlistrikan dengan menggunakan energi surya. Apabila pemasangan sistem tersebut pada kapal penangkap ikan tersebut dapat terealisasi, maka pada gilirannya kesejahteraan para nelayan di wilayah ini akan meningkat. Kapal yang dirancang direncanakan menggunakan material / bahan baku yang terbuat dari aluminium, fiberglass atau kayu. Material / bahan baku kapal tersebut masih mudah ditemukan di wilayah Jabodetabek. Desain kapal penangkap ikan tersebut meliputi menentukan ukuran pokok, pembuatan gambar garis, penyusunan rencana umum, desain konstruksi, diagram stabilitas, daya mesin, perlistrikan, tonage dan stabilitas. Hasil kebutuhan listrik maksimal 495 Watt, panel surya 2 unit, dan baterai/accu 3 unit.
\end{abstract}

Kata Kunci: kapal penangkap ikan, energi surya, kesejahteraan, ramah lingkungan

\section{PENDAHULAN}

Potensi sumber daya perikanan laut Indonesia besarnya 6.6 juta ton/tahun, tetapi baru sebagian yang dapat ditangkap oleh nelayan Indonesia yaitu \pm 4.7 juta ton/tahun, sebagian lagi dicuri oleh nelayan-nelayan negara tetangga. Hal ini disebabkan terbatasnya jumlah dan besar ukuran kapal ikan yang beroperasi. Menurut Kepala Badan Pengembangan Sumber Daya Manusia Kelautan dan Perikanan Kementerian Kelautan dan Perikanan RI memperkirakan potensi jumlah tangkapan sumber daya ikan yang diperbolehkan di wilayah pengelolaan perikanan Indonesia mencapai 12.5 juta ton [1].

Salah satu wilayah yang mempunyai potensi perikanan tangkap adalah Kecamatan Pakuhaji Kabupaten Tangerang Provinsi Banten. Kecamatan Pakuhaji mempunyai wilayah pesisir yang berhadapan langsung dengan Laut Jawa. Wilayah ini memiliki garis pantai \pm 6 (enam) kilometer. Wilayah ini terdapat Pangkalan Pendaratan Ikan (PPI) Cituis, tepatnya berada di Desa Surya Bahari [2].

Wilayah Desa Surya Bahari Kecamatan Pakuhaji Kabupaten Tangerang sangat potensial untuk armada perikanan tangkap. Di wilayah ini telah tersedia Pangkalan Pendaratan Ikan (PPI) yang mampu untuk berlabuh kapal perikanan sampai dengan maksimum ukuran kapal 10 Gross Tonnage (GT). Kapal perikanan dengan ukuran 10 GT tersebut diperuntukkan pada perairan pedalaman dan perairan kepulauan. Dalam rangka meningkatkan kemampuan para nelayan di Kecamatan Pakuhaji tersebut, maka perlu dibangun kapal penangkap ikan yang sesuai untuk wilayah ini dan hemat energi. Apabila 
desain/perancangan dan pembangunan kapal penangkap ikan ini dapat terealisasi, maka pada gilirannya kesejahteraan para nelayan di wilayah ini akan meningkat. [3, 4].

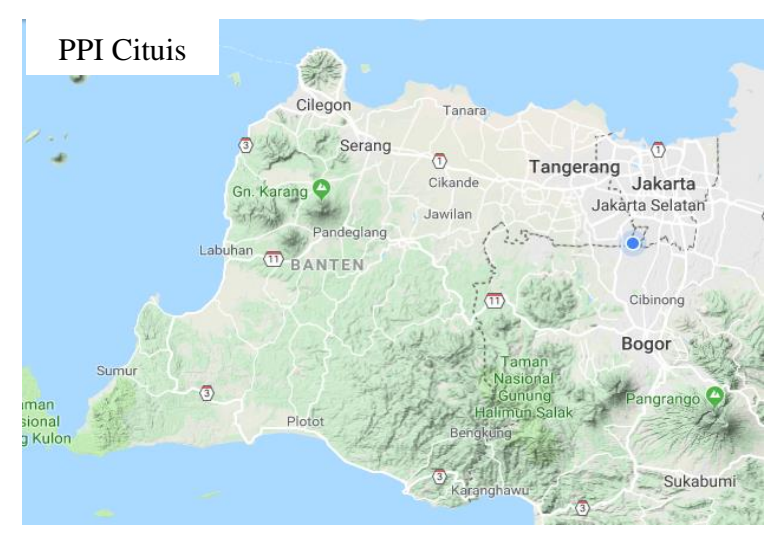

GAMBAR 1. Peta PPI Cituis

Kapal yang dirancang direncanakan menggunakan material yang pada umumnya digunakan untuk membangun kapal dengan ukuran yang relatif kecil [5]. Desain kapal tersebut meliputi penentuan ukuran pokok, pembuatan gambar garis, penyusunan rencana umum, desain konstruksi, diagram stabilitas, daya mesin, daya listrik energi surya, dan tonage.

Untuk memenuhi kriteria hemat energi dan ramah lingkungan maka alat pembangkit listrik untuk penerangan pada malam hari dan keperluan lain maka kapal yang dirancang ini direncanakan menggunakan energi surya [6].

Panjang dermaga PPI Cituis lebih kurang 150 meter, dengan kedalaman kolam lebih kurang dari $70 \mathrm{~cm}$. Dapat menampung \pm 10 kapal penangkap ikan berukuran rata-rata 10 GT. Luas lahan pendaratan ikan tangkap tidak lebih dari 5 hektar. Dari batasanbatasan fasilitas pendaratan yang tersedia, maka dapat dirancang Kapal Penangkap Ikan maksimal 10 GT. Permasalahan energi listrik untuk keperluan penerangan pada waktu operasional malam hari dan kebutuhan listrik lainnya merupakan permasalahan tersendiri, yaitu yang selama ini menggunakan generator terkendala oleh terbatasnya pasokan mahalnya bahan bakar minyak. Penggunaan aki penyimpan strum diidentifikasi cepat rusak karena sering bongkar pasang pada waktu pengisian strum. Untuk mengatasi permasalahan energi listrik tersebut dengan alternatif penggunaan intalasi panel surya sebagai penyedia energi listrik sebagai pengganti sistem energi listrik sebelumnya.

Untuk merancang kapal penangkap ikan yang akan dioperasikan khususnya di wilayah perairan Kabupaten Tangerang ini tentunya ada beberapa hal yang menjadi dasar acuan. Salah satu acuan tersebut adalah kriteria/kelas pelabuhan [7].

TABEL 1. Karakteristik PPI

\begin{tabular}{c|l|l}
\hline No & \multicolumn{1}{|c|}{ Kriteria Pelabuhan Perikanan } & \multicolumn{1}{c}{ PPI } \\
\hline 1 & Daerah operasional kapal ikan yang dilayani & $\begin{array}{l}\text { Perairan pedalaman dan perairan } \\
\text { kepulauan }\end{array}$ \\
\hline 2 & Fasilitas tambat / labuh kapal & $3-10 \mathrm{GT}$ \\
\hline 3 & Panjang dermaga dan Kedalaman kolam & $50-100 \mathrm{~m}$ dan $>2 \mathrm{~m}$ \\
\hline 4 & Kapasitas menampung Kapal & $\begin{array}{l}>60 \mathrm{GT} \text { (ekivalen dengan 20 buah kapal } \\
\text { berukuran 3 GT) }\end{array}$ \\
\hline 5 & Volume ikan yang didaratkan & - \\
\hline 6 & Ekspor ikan & Tidak \\
\hline 7 & Luas lahan & $2-5 \mathrm{Ha}$ \\
\hline 8 & Fasilitas pembinaan mutu hasil perikanan & Tidak \\
\hline 9 & $\begin{array}{l}\text { Tata ruang (zonasi) pengolahan / } \\
\text { pengembangan industri perikanan }\end{array}$ & Tidak \\
\hline
\end{tabular}

Dengan demikian, tujuan dari penelitian ini adalah melakukan perancangan atau desain kapal penangkap ikan 10 GT untuk wilayah perairan Kecamatan Pakuhaji Kabupaten Tangerang. Pada penelitian ini diharapkan dapat memberikan manfaat mendapatkan bentuk dan ukuran kapal penangkap ikan yang sesuai wilayah perairan, memberikan 
masukan kepada Pemerintah Kabupaten Tangerang khususnya Dinas Perikanan dalam rangka peningkatan pemberdayaan masyarakat nelayan. Kapal penangkap ikan (Fishing Vessel) adalah jenis kapal perikanan yang secara khusus dipergunakan untuk menangkap ikan termasuk menampung, menyimpan, mendinginkan atau mengawetkan. Alat penangkap ikan yang hanya diperbolehkan digunakan diperairan sekitar garis ZEEI adalah jenis pukat dan jaring insang.

Pangkalan Pendaratan Ikan (PPI) merupakan pelabuhan perikanan tipe D. Pelabuhan perikanan ini memiliki lahan $2-5 \mathrm{Ha}$, dan dirancang untuk melayani kapal perikanan berukuran 3 - 10 GT. Pelabuhan perikanan ini dapat menampung 6 kapal atau 60 GT sekaligus. Pelabuhan perikanan ini melayani kapal ikan yang beroperasi di perairan pantai/pedalaman dan perairan kepulauan [8].

\section{METODOLOGI}

Metode penelitian dalam Pemanfaatan Energi Surya pada Kapal Penangkap Ikan 10 GT sebagai Sarana Perlistrikan Alternatif di PPI Cituis Kabupaten Tangerang ini meliputi alur penelitian dan uraian alur penelitian seperti pada gambar 2 .

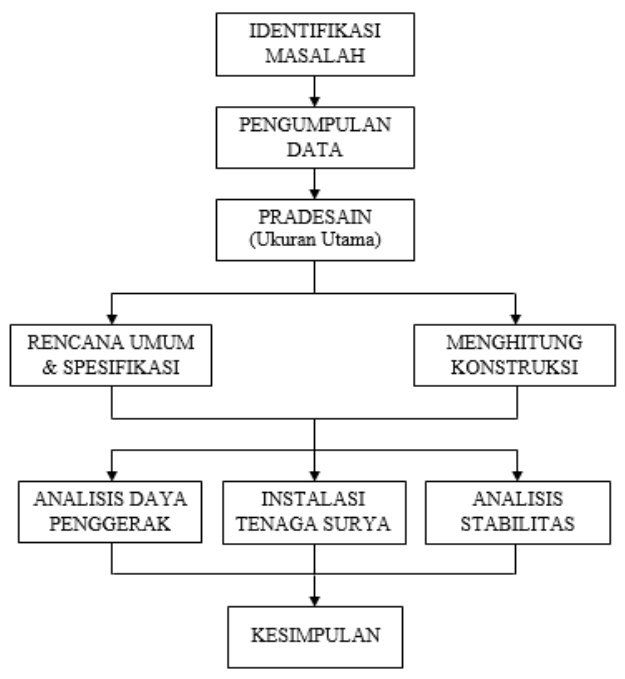

GAMBAR 2. Bagan alir metode penelitian.

Uraian metode penelitian dijelaskan menurut tabel 2.

TABEL 2. Uraian Metode Penelitian

\begin{tabular}{lll}
\hline \multicolumn{1}{c}{ Kegiatan } & \multicolumn{1}{c}{ Metode } & \multicolumn{1}{c}{ Luaran } \\
\hline $\begin{array}{l}\text { Identifikasi masalah dan } \\
\text { Pengumpulan Data }\end{array}$ & Literatur, survei & $\begin{array}{l}\text { Data Kapal Penangkap Ikan 10 GT sebagai } \\
\text { pembanding dan data PPI Cituis }\end{array}$ \\
\hline Praperancangan & $\begin{array}{l}\text { Metode rasio perbandingan } \\
\text { Ukuran Pokok kapal: } \\
\text { L/B, B/T, D/T }\end{array}$ & $\begin{array}{l}\text { Ukuran Pokok kapal: Loa; Lpp; Lwl; B; } \\
\text { D; T. }\end{array}$ \\
\hline Perkiraan Berat Kapal & $\begin{array}{l}\text { Acuan kapal pembanding } \\
\text { dan rumus-rumus umum }\end{array}$ & $\begin{array}{l}\text { Bobot Mati (Deadwieght) dan Berat Kapal } \\
\text { Kosong (Lightweight) }\end{array}$ \\
\hline $\begin{array}{l}\text { Penentuan Rencana Umum } \\
\text { General Arrangement) }\end{array}$ & $\begin{array}{l}\text { Regulasi umum kapal dan } \\
\text { software CAD }\end{array}$ & Gambar Konsep Rencana Umum \\
\hline $\begin{array}{l}\text { Penentuan Peralatan Kapal dan } \\
\text { Pembuatan Spesifikasi }\end{array}$ & $\begin{array}{l}\text { Regulasi umum kapal dan } \\
\text { pemilihan peralatan kapal }\end{array}$ & $\begin{array}{l}\text { Peralatan sistem penggerak kapal; } \\
\text { akomodasi; sistem tambat; keselamatan; }\end{array}$ \\
& $\begin{array}{l}\text { termasuk sistem } \\
\text { perlistrikan }\end{array}$ & Spesifikasi dan prosedur operasi peralatan. \\
\hline Penentuan Konstruksi & $\begin{array}{l}\text { Peraturan Biro Klasifikasi } \\
\text { kapal }\end{array}$ & $\begin{array}{l}\text { Penentuan beban, jumlah sekat, frame, } \\
\text { pelat lambung, pelat deck. }\end{array}$ \\
\hline Perhitungan Tonnage & Standar IMO & Besaran volume seluruh ruangan \\
\hline Penentuan Daya Penggerak & Menggunakan analisis & $\begin{array}{l}\text { Tahanan kapal dan tenaga kuda kecepatan } \\
\text { tertentu, BHP. }\end{array}$ \\
\hline $\begin{array}{l}\text { Penghitungan energi surya dan } \\
\text { instalasinya }\end{array}$ & Pullspeed & $\begin{array}{l}\text { Besaran daya yang dihasilkan dan } \\
\text { rangkaian instalasi }\end{array}$ \\
\hline
\end{tabular}




\begin{tabular}{lll}
\hline Perhitungan Stabilitas & Menggunakan Teori & KG dan LCG kondisi kosong dan penuh. \\
& Stabilitas dan Trim & GZ 0 ${ }^{0}$ sd. sudut tengggelam. \\
\hline
\end{tabular}

\section{HASIL DAN PEMBAHASAN}

\section{Pangkalan Pendaratan Ikan (PPI) Cituis}

Pengelolaan dan pembinaan PPI Cituis berada di bawah Dinas Kelautan dan Perikanan Kabupaten Tangerang. Peran PPI Cituis adalah memajukan perikanan tangkap di daerahnya yang meliputi aspek produksi, pengolahan dan pemasaran. Operasionalnya sangat dipengaruhi oleh hasil tangkapan yang didapatkan. Kapasitas fasilitas PPI Cituis akan mempengaruhi kelancaran aktivitas kepelabuhanan untuk memenuhi fungsi secara optimal. PPI Cituis merupakan salah satu dari 7 (Tujuh) PPI di Kabupaten Tangerang yang memberikan kontribusi PAD Kabupaten Tangerang. Fasilitas, produksi, dan kebutuhan PPI Cituis diuraikan seperti tabel 3.

TABEL 3. PPI Cituis

\begin{tabular}{c|l|l}
\hline No & \multicolumn{1}{|c|}{ Sarana Prasarana } & \multicolumn{1}{c}{ Uraian } \\
\hline 1. & Panjang Dermaga & \pm 60 meter \\
\hline 2. & Kolam Dermaga & $\begin{array}{l}\text { Pasang } \pm 2,5 \text { meter } \\
\text { Surut } \pm 1,5 \text { meter }\end{array}$ \\
\hline 3. & Kunjungan Kapal & $\pm 30 \mathrm{kapal} /$ hari \\
\hline 4. & Alat tangkap & Sondong (pukat dorong) \\
\hline 5. & Hasil tangkapan & Udang, bilis, petek, dan tembang \\
\hline 6. & Jumlah tangkapan & $\pm 120 \mathrm{~kg} / \mathrm{kapal} /$ hari \\
\hline 7. & BBM & 7500 liter / hari \\
\hline 8. & Es balok & \pm 60 balok / hari \\
\hline
\end{tabular}

Hampir semua fasilitas PPI Cituis dianggap sudah memadai, kecuali kapasitas menampung kapal yang perlu ditambah, karena kadang-kadang kapal yang akan bersandar harus menunggu antrian.

\section{Rencana Umum}

Rencana umum disajikan untuk menjelaskan rancang bangun kapal ikan kapasitas 10 GT dengan mesin penggerak satu (1) unit mesin (marine engine) diesel $54 \mathrm{HP}$ dan dapat beroperasi di pesisir perairan 10 mil dari pantai Pakuhaji selama 10 jam.

\section{Ukuran Utama}

Panjang seluruh (LOA) : 14.00 meter

Panjang geladak (LDK) : 13.00 meter

Panjang Garis Air (LWL) : 12.53 meter

Lebar, maximum (B max) : 3.10 meter

Lebar, moulded (B mld) : 3.00 meter

Tinggi, moulded (D mld) : 1.60 meter

Sarat tengah kapal $(\mathrm{T}) \quad: \quad 0.70$ meter

Mesin penggerak : $54 \mathrm{HP}$ (horse power)

Kecepatan : 7 - 8 knot

Lama operasi $\quad: 10$ jam

Jarak jelajah $\quad: 80 \mathrm{Nm}$ (nautical mile)

Kapasitas

Palka Ikan (Ikan + Es) : 4 Ton

Bahan Bakar : 220 liter

Air Tawar : 240 liter

Awak kapal/komplemen $: 6$ orang

Gross Register Tonnage (GRT) : 10 GT (gross tonnage)

Propulsi

Mesin diesel $\quad: 1$ unit

Output mesin (BHP) : : $54 \mathrm{HP}$

Putaran maximum $\quad: 1.500$ RPM 
Fixed propeller $\quad: 1$ unit

Kecepatan dinas pada Maksimum Continuous Rating (MCR) 90\% dengan Sea Margine $15 \%$ mesin utama, dengan dua per tiga (2/3) kapasitas bahan bakar \& air tawar, 6 (enam) orang, pada dasar lambung kapal bersih/licin, 8.00 knot dalam keadaan air tenang. Pada waktu operasional dengan kecepatan penuh 7.50 knot kondisi mesin dibebani pada MCR 90\% mampu berlayar menempuh total jarak jelajah $80 \mathrm{Nm}$ dengan endurance 10 jam. Dalam lambung dipasang 3 (tiga) buah sekat kedap air melintang membagi lambung kapal menjadi 4 (empat) buah ruangan (compartment). Tempat steering gear dan 1 (satu) unit tangki air tawar (TAT) ditempatkan dalam ruang ceruk buritan, separti pada tabel 4 .

TABEL 4. Tanki air tawar (TAT)

\begin{tabular}{c|l|c|c}
\hline No. & \multicolumn{1}{|c|}{ Uraian } & Jumlah & Satuan \\
\hline 1 & Komplemen & 6 & orang \\
\hline 2 & Total tenaga mesin & 54 & $\mathrm{Hp}$ \\
\hline 3 & Waktu jelajah & 0.42 & hari \\
\hline 4 & C awak kapal & 16 & $1 / \mathrm{hari}$ \\
\hline 5 & C mesin & 3.0 & $\mathrm{~kg} / \mathrm{Hp}$ \\
\hline 6 & Kebutuhan pendingin mesin & 195 & $\mathrm{~kg}$ \\
\hline 7 & Kebutuhan air tawar minum \& sanitasi & 40 & $\mathrm{~kg}$ \\
\hline & Tangki Air Tawar $(\mathbf{C})$ & $\mathbf{2 3 5}$ & $\mathbf{k g}$ \\
\hline
\end{tabular}

Dalam ruang mesin ditempatkan 1 (satu) unit Tangki Bahan Bakar (TBB) seperti pada Tabel 5 berikut ini. Ruang dilengkapi ventilasi natural yang cukup agar dapat menjaga suhu kamar mesin maksimum $40^{\circ} \mathrm{C}$;

TABEL 5. Tangki bahan bakar (TBB)

\begin{tabular}{c|c|c|c|c}
\hline \multirow{2}{*}{ Tangki-tangki } & \multicolumn{2}{|c|}{ Kebutuhan } & \multicolumn{2}{c}{ Volume Tangki $\left(\mathbf{m}^{\mathbf{3}}\right)$} \\
\cline { 2 - 5 } & Berat $($ Kg) & Volume $(\mathbf{L})$ & Tersisa & Expansi \\
\hline Tangki Bahan Bakar (TBB) & 158 & 186 & 204 & 213 \\
\hline Total & $\mathbf{1 5 8}$ & $\mathbf{1 8 6}$ & $\mathbf{2 0 4}$ & $\mathbf{2 1 3}$ \\
\hline
\end{tabular}

Dua (dua) buah palka ikan sebagai tempat penyimpanan ikan dan es dengan kapasitas seperti pada Tabel 6 berikut ini.

TABEL 6. Palka-palka ikan

\begin{tabular}{c|c|c|c|c|c}
\hline \multirow{2}{*}{ Ruang Palka Ikan (PI) } & \multicolumn{2}{|c|}{ Volume $\left(\mathbf{m}^{\mathbf{3}}\right)$} & SWR 76\% & Ikan 57\% & Es 43\% \\
\cline { 2 - 6 } & Bruto & Grain & Ton & Ton & Ton \\
\hline Palka Ikan No.1 & 6.81 & 5.45 & 4.14 & 2.36 & 1.78 \\
\hline Palka Ikan No.2 & 4.73 & 3.78 & 2.88 & 1.64 & 1.24 \\
\hline Jumlah & $\mathbf{1 1 . 5 4}$ & $\mathbf{9 . 2 3}$ & $\mathbf{7 . 0 2}$ & $\mathbf{4 . 0 0}$ & $\mathbf{3 . 0 2}$ \\
\hline
\end{tabular}

Catatan: Batas kapasitas palka ikan yang diijinkan 4 ton pada sarat air maximum $0.70 \mathrm{~m}$

Ruang ceruk haluan, gudang peralatan bahari ditempatkan di ruang ceruk haluan di atas grating. Rumah kemudi / ruang anjungan berfungsi sebagai ruang untuk mengendalikan kapal dan sebagai tempat tidur Nakhoda kapasitas 1 (satu) orang, dilengkapi dengan peralatan kemudi, navigasi dan alat komunikasi. Ruang akomodasi (ABK) berfungsi sebagai tempat tidur ABK dengan kapasitas 6 (enam) orang.

\section{Perlengkapan / Inventaris}

\section{Perlengkapan Tambat dan Sauh}

- Jangkar tongkat $20 \mathrm{~kg}$, besi

- Rantai jangkar diameter $16 \mathrm{~mm}$

- Segel

- Tali jangkar nylon diameter $18 \mathrm{~mm}$ x $50 \mathrm{~m}$

- Tali tambat diameter 14 mm x 2 buah @ 20 m

- Tali lempar/buang 8 mm @ 20 m

- Ban bekas

- Bow roller 


\section{Perlengkapan Keselamatan}

- Baju penolong (life jacket) : 8 buah

- Pelampung bulat (ring buoy) : 2 buah

- Kotak P3K berisikan obat-obatan : 1 buah

\section{Perlengkapan Pemadam Kebakaran}

- Pemadam kerbakaran tipe powder $2.5 \mathrm{~kg}$ : 1 buah

\section{Perlengkapan Navigasi}

- Kompas air raksa 3" : 1 buah

- Bendera Nasional : 1 buah

- Bendera isyarat : 1 buah

- Peta laut Indonesia : 1 set

- Mistar jajar: 2 buah

- Jangka : 2 buah

\section{Perelengkapan Panel Surya}

- Panel surya : 2 unit di atas wheelhouse

- Baterai : 3 unit di atas ruang mesin

\section{Perlengkapan Alat Tangkap}

Perlengkapan alat tangkap jaring insang (Gill Net)

TABEL 7. Uraian alat tangkap gillnet

\begin{tabular}{c|l|c}
\hline No & \multicolumn{1}{|c}{ Uraian } & Ukuran \\
\hline 1 & Gill Nett D 6 & 2.5 inchi \\
\hline 2 & Gill Nett D 9 & 2.5 inchi \\
\hline 3 & Gill Nett D 12 & 2.5 inchi \\
\hline 4 & Gill Nett D 15 & 2.5 inchi \\
\hline 5 & Pelampung Y 8 & \\
\hline 6 & Pelampung Y 18 & 4 \\
\hline 7 & Tali PE "SIGUL" (Blue) & 5 \\
\hline 8 & Tali PE "SIGUL" (Blue) & 6 \\
\hline 9 & Tali PE "SIGUL" (Blue) & 8 \\
\hline 10 & Tali PE "SIGUL" (Blue) & 10 \\
\hline 11 & Tali PE "SIGUL" (Blue) & \\
\hline
\end{tabular}
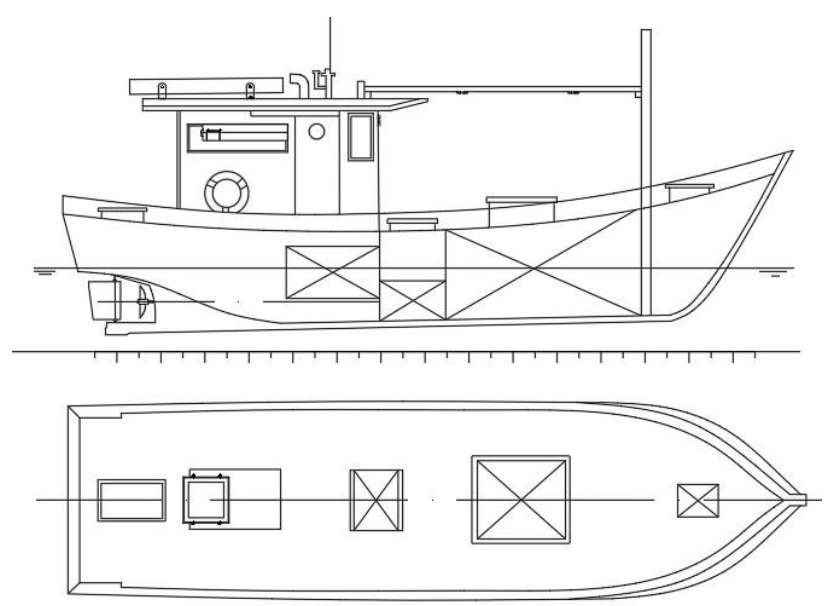

GAMBAR 3. Rencana umum kapal penangkap ikan 10 GT

\section{Konstruksi}

Kapal penangkap ikan ini dibuat dengan bahan baku kayu. Hal tersebut dimaksudkan biaya pembuatan kapal relatif murah namun kekuatan konstruksi juga relafif lebih baik, mengingat di PPI Cituis areal bersandar agak sempit sehingga sering berbenturan antara kapal yang satu dengan yang lain. Pada pembuatan kapal kayu ada beberapa hal yang perlu diperhatikan, diantaranya komposisi bahan kualitas baik, baik itu untuk Lunas (keel), Bottom, Lambung, Gading-gading / kerangka dan bagian lain. Selain komposisi 
bahan ketebalan bahan yang digunakan juga merupakan hal yang perlu diperhatikan $[9$, $10]$.

Semua material beserta perlengkapannya yang dipergunakan untuk pembuatan kapal perikanan ini adalah baru, dengan material yang mempunyai kualitas uji bahan yang baik dan khusus digunakan di laut.

Material yang dipakai untuk struktur lambung menggunakan bahan kayu dengan ketebalan minimal peruntukan sebagai berikut : Lunas (keel), Dasar (Bottom), Lambung (Hull), Gading-gading / Kerangka (Frame), Lantai Geladak (Deck), dan Bangunan Atas (Wheelhouse).

\section{Tonnage}

Tonnage merupakan volume ruang pada sebuah kapal dengan satuan Register Tonnage $(\mathrm{RT})$, dimana $1 \mathrm{RT}=100 \mathrm{ft}^{3}$ atau setara dengan $2,83 \mathrm{~m}^{3}$. Penentuan GT kapal menurut cara pengukuran dalam negeri, dihitung sesuai dengan ketentuan dalam Keputusan Dirjen PERLA No. PY.67/1/16-02, menggunakan hubungan GT $=0.25 \times \mathrm{V}$, dimana nilai 0.25 adalah nilai konversi dari satuan meter kubik ke ton register dan $\mathrm{V}$ adalah jumlah isi dari ruangan di bawah geladak atas ditambah dengan ruangan-ruangan di atas geladak atas yang tertutup sempurna yang berukuran tidak kurang dari 1 meter kubik.

$\mathrm{V}=(\mathrm{L} \times \mathrm{B} \times \mathrm{D} \times \mathrm{f})+\mathrm{V}$ bangunan atas, $\mathrm{V}$ bangunan atas diperkirakan $=3 \times 2.5 \times 2.5=$ $30 \mathrm{~m}^{3} . \mathrm{V}=(\mathrm{L} \times \mathrm{B} \times \mathrm{D} \times \mathrm{f})+\mathrm{V}$ bangunan atas $=(13 \times 3.1 \times 1.8 \times 0.5)+17.75=42.23$ $\mathrm{m}^{3}$. Sehingga GT $=0.25 \times \mathrm{V}=0.25 \times 42.23=10.36$ mendekati $10 \mathrm{GT}$. NT $=0.6 \mathrm{GT}=$ $0.6 \times 10=6$.

Hasil perhitungan GT kapal 10.36 mendekati ukuran GT kapal yang dikehendaki yaitu Kapal Penangkap Ikan 10 GT.

Perhitungan stabilitas periode oleng yaitu $0.5 \times \mathrm{Cr}=0.373+0.023 \times(\mathrm{B} / \mathrm{d})-0.043$ $(\mathrm{Lwl} / 100)=0.4475$, sehingga $\mathrm{Cr}=0.995, \mathrm{GM}_{\mathrm{T}}=1.354 \mathrm{~m}$ sehingga dengan menggunakan hubungan $\mathrm{T}=\mathrm{Cr} \times \mathrm{B} /\left(\mathrm{GM}_{\mathrm{T}}\right)^{1 / 2}=8.64 \mathrm{~s}$. Periode oleng kapal 8.64 (s) dapat dikatakan kapal mempunyai stabilitas yang cukup nyaman pada gerak kapal dan untuk awak kapal.

\section{Daya Listrik dari Panel Surya}

Tegangan panel surya / solar cell yang dihasilkan akan digunakan oleh charge controller untuk mengisi baterai ${ }^{[11]}$. Untuk menghidupkan beban perangkat AC (alternating current) seperti lampu-lampu navigasi, televisi, radio, alat komunikasi, dan lain-lain, maka arus baterai disupply oleh inverter.

TABEL 8. Keperluan daya listrik kapal

\begin{tabular}{c|l|c|c|c}
\hline No. & \multicolumn{1}{|c|}{ Peralatan } & Daya Rata-rata (watt) & Kuantitas & Jumlah (watt) \\
\hline 1 & Penerangan ruang & 20 & 10 & 200 \\
\hline 2 & Lampu sorot & 100 & 1 & 100 \\
\hline 3 & Televisi & 75 & 1 & 75 \\
\hline 4 & Radio & 35 & 1 & 35 \\
\hline 5 & Alat komunikasi & 75 & 1 & 75 \\
\hline 6 & Lain-lain & 10 & 1 & 10 \\
\hline & Jumlah & & & $\mathbf{4 9 5}$ \\
\hline
\end{tabular}

Instalasi pembangkit listrik dengan tenaga surya membutuhkan perencanaan mengenai kebutuhan daya yaitu jumlah pemakaian, jumlah panel surya dan jumlah baterai. Jumlah panel surya yang dibutuhkan, satu panel kita hitung 100 Watt (perhitungan adalah 5 jam maksimun tenaga surya). Kebutuhan panel surya adalah $495 /(100 \times 5)=1$ panel surya. Jumlah kebutuhan batere 12 Volt dengan masing-masing 100 Ah. Kebutuhan baterai minimun (baterai hanya digunakan 50\% untuk pemenuhan kebutuhan listrik), dengan demikian kebutuhan daya kita kalikan $2 \times$ lipat : $495 \times 2=990$ Watt hour $=990 / 12$ Volt / $100 \mathrm{Amp}=2$ batere $100 \mathrm{Ah}$. Kebutuhan baterai dengan pertimbangan dapat melayani kebutuhan 2 hari tanpa sinar matahari adalah $495 \times 2 \times 2=1980$ Watt hour $=1980 / 12$ Volt / $100 \mathrm{Amp}=3$ baterai $100 \mathrm{Ah}$. Jumlah panel surya yang dibutuhkan, satu panel kita hitung 100 Watt dengan 5 jam maksimum tenaga surya. Kebutuhan panel surya (1980 / $100 \times 5)=2$ panel surya. 


\section{KESIMPULAN}

Dari hasil perbandingan ukuran pokok dan perlengkapan, serta perhitungan kebutuhan kelistrikan untuk kapal penangkap ikan kapasitas $10 \mathrm{GT}$, maka dapat disimpulkan bahwa pemasangan sistem panel surya di kapal perikanan akan dapat menghemat konsumsi bahan bakar minyak dan menambah umur teknis baterai. Bagi pemilik kapal ikan, untuk kebutuhan listrik di atas kapal lebih baik dipasang sistem panel surya, hal ini dapat menghemat konsumsi bahan bakar dan baterai akan lebih awet.Instansi terkait dalam hal ini Dinas Kelautan dan Perikanan Kabupaten Tangerang agar dapat memfasilitasi untuk PPI Cituis meningkatkan kemampuan fasilitas pokok, fasilitas fungsional, maupun fasilitas penunjang sehingga kedepan akan dapat disinggahi oleh kapal penangkap ikan yang berukuran di atas $10 \mathrm{GT}$.

\section{DAFTAR PUSTAKA}

[1] Anwar Limar Ramadhan, Ery Diniardi, Soni Hari Mukti. (2016). Analisis Desain Sistem Pembangkit Listrik Tenaga Surya Kapasitas 50 WP. Jurnal Teknik Universitas Muhammadiyah, 37 (2).

[2] Bachtiar M. (2006). Prosedur Pemasangan Sistem Pembangkit Listrik Tenaga Surya Untuk Perumahan (Solar Home System). Jurnal SMARTek Vol 4, No. 3.

[3] Bambang Sudjasta, Yuhani Djaya. (2015). Desain Kapal Penangkap Ikan 10 GT Untuk Perairan Panimbang Pandeglang. Jurnal Ilmiah FT-UPNVJ Bina Teknika Volume 11 Nomor 2 Edisi Desember 2015.

[4] Bambang Sudjasta, Purwo Joko Suranto. (2017). Desain Bis Air Ramah Lingkungan Sebagai Sarana Transportasi Alternatif di Provinsi DKI Jakarta. Jurnal Ilmiah FT-UPNVJ Bina Teknika Volume 13 Nomor 2 Edisi Desember 2017.

[5] Dafi Dzulfikar, Wisnu Broto. (2016). Optimalisasi Pemanfaatan Energi Listrik Tenaga Surya Skala Rumah Tangga. Prosiding Seminar Nasional Fisika (EJournal). Volume V, Oktober.

[6] David Setia Maradong. (2016). Potensi Besar Perikanan Tangkap Indonesia. Artikel Kemaritiman Humas Sekretariat Kabinet.

[7] Ditjen Perikanan Tangkap, KKPRI, (2014), Buku Laporan Tahunan Statistik Perikanan Tangkap Tahun 2014.

[8] Iswadi Nur, 2013, Metode Sederhana Untuk Memilih Jenis Lambung Kapal Kecil (Boat) Sesuai Dengan Fungsinya Berdasarkan Pertimbangan Stabilitas Yang Cocok Agar Dapat Menghindari Kecelakaan Di Laut, Jurnal Ilmiah FT-UPNVJ Bina Teknika Volume 9 Nomor 2 Edisi Desember.

[9] Jatmiko, Angga. (2012). Intensitas Cahaya Matahari Terhadap Keluaran Panel Sel Surya. Simposium Nasional RAPI XI FT-UMS.

[10] Munro-Smith. (2016). Naval Architecture. Ernest Benn Limited, London.

[11] Prasetyo, R. (2012). Sel Surya Berbasis Titania Sebagai Sumber Energi Listrik Alternatif. Prosiding Seminar Nasional Penelitian, Pendidikan dan Penerapan Mipa, Fakultas MIPA, Universitas Negeri Yogyakarta, 2 Juli 2012. 